Volume 6 Nomor 2, Agustus 2021, halaman 222 - 237.

\title{
High School Students' Algebraic Thinking Ability in Solving Linear Program Problems
}

\section{Kemampuan Berpikir Aljabar Siswa SMA Dalam Menyelesaiakan Masalah Program Linear}

\author{
Dannix Aprildat ${ }^{1}$, Dori Lukman Hakim ${ }^{2}$ \\ ${ }^{1}$ Department of Mathematics Education, Universitas Singaperbangsa Karawang, \\ 1710631050028@ student.unsika.ac.id \\ ${ }^{2}$ Department of Mathematics Education, Universitas Singaperbangsa Karawang, \\ dorilukmanhakim@fkip.unsika.ac.id
}

\begin{abstract}
ABSTRAK
Aljabar merupakan bagian dari matematika yang berperan penting dalam proses pemecahan masalah dalam matematika dan bidang ilmu lainnya. Mulai dari konsep hingga cara berpikir aljabar. Sehingga penting bagi siswa untuk menguasai keterampilan berpikir aljabar. Oleh karena itu, penelitian ini akan memberikan gambaran tentang kemampuan berpikir aljabar dalam menyelesaikan masalah matematika. Model penelitian yang digunakan adalah deskriptif analisis kualitatif. Penelitian ini dilakukan di salah satu SMA di Kabupaten Karawang. Hasil penelitian menunjukkan bahwa proses berpikir aljabar yang dilakukan oleh siswa kelas XI masih tergolong rendah. Ada enam poin penting dalam penelitian ini mengenai kekurangan proses berpikir aljabar siswa kelas XI dalam menyelesaikan masalah pada materi program linier dua variabel.
\end{abstract}

Kata Kunci: Berpikir Aljabar, Pemrograman Linier, Pemecahan Masalah.

\section{ABSTRACT}

Algebra is a part of mathematics that plays an important role in the process of solving problems in mathematics and other fields of science. Starting from concepts to algebraic ways of thinking. So it is important for students to master algebraic thinking skills. Therefore, this study will provide an overview of algebraic thinking skills in solving mathematical problems. The research model used is descriptive qualitative analysis. The research was conducted at one of the high schools in Karawang district. The results showed that the algebraic thinking process carried out by class XI students was still relatively low. There are six important points in this study regarding the shortcomings of the algebraic thinking process of class XI students in solving problems in two-variable linear programming material.

Keyword(s): Algebraic Thinking, Linear Programming, Problem Solving.

How to Cite: Aprildat, D., \& Hakim, D. L. (2021). High School Students' Algebraic Thinking Ability in Solving Linear Program Problems. Mathline: Jurnal Matematika dan Pendidikan Matematika, Vol. 6 No. 2, 222 - 237.

DOI: https://doi.org/10.31943/mathline.v6i2.216

\section{PRELIMINARY}

Mathematics is a subject that prioritizes the growth of critical thinking for students because of its logical, systematic, and abstract nature. In line with Retnowati, (2017) Mathematics learning can train logical thinking skills so that students are able to reason 
and provide arguments systematically in accordance with mathematics. In addition, mathematics is the basis for several other fields of knowledge, both at the school and college level. Understanding mathematics helps students more easily develop their potential in other fields of science. This is in line with Mulbar, (2015) that mathematics is the science that underlies the development of modern technology and has an important role in other branches of science.

The combination of abstract numbers and numbers, calculations, and logic makes mathematics more difficult for students. In line with what Nurjanah \& Hakim stated, (2019) mathematics is considered difficult because it is tied to numbers, calculations, and logic. In addition to its nature, difficulties in mathematics are also caused by an ineffective learning process. Resulting in students' understanding of mathematics to be less than optimal.

Without realizing it, the existence of mathematics also helps students in daily activities, there are things that are complicated, even something simple. Such as determining the amount of money needed to buy 2 pencils at a price of Rp. 1,500 per piece or determine the final savings amount with compound interest. From these two problems can be solved by algebraic concepts. Algebra is a part of mathematics that can make it easier for students to solve problems.

However, many students have difficulty understanding and mastering algebraic concepts and ways of thinking. There are students who have difficulty in mathematical modeling as happened in the research of Kurniasih \& Hakim, (2019). Mathematical modeling is the process of presenting a problem in the form of a mathematical model. The same problem also occurs in the research of Turrosifah \& Hakim, (2019), students have not been able to model mathematics based on available geometric information. Mathematical modeling is one aspect of the concept of algebra that is in direct contact with the concepts of generalization and abstraction. In the abstraction process, students have difficulty in extracting and connecting symbols based on the generalization results. In Yusrina \& Masriyah's research, (2019) students with low abilities did not show the abstraction process. In addition, it was also found that students had difficulties in solving problems analytically, as found by Arfianto \& Hakim, (2019). Students tend to be unable to explain and draw conclusions from a problem.

These problems are very detrimental to students because algebra is very important to be understood by students, both concepts and ways of thinking. The concept of algebra 
can help students understand and solve a problem. Algebra can help students become more familiar with abstract forms of mathematics.

The ability to think algebraically is a thinking activity that is needed in learning mathematics that is able to grow mathematical problem solving skills by thinking algebraically. Students carry out activities carried out in an effort to analyze, represent, and generalize to symbols, patterns, and numbers that are presented in the form of tables, words, pictures, diagrams and mathematical expressions (Utami et al., 2020) The ability to think algebraically arises when given a mathematical problem. The right problem in exploring algebraic thinking skills is a mathematical problem that has algebraic concepts (Hardianti \& Kurniasari, 2019) Some mathematical materials that involve algebraic concepts in solving problems are geometric transformations, matrices, algebra, linear algebraic equations and inequalities, linear programming, and other material.

While algebra according to Lew, (2004) "Algebra is a subject dealing with expressions with symbols and the extended numbers beyond the whole numbers in order to solve equations, to analyze functional relations, and to determine the structure of the representational system which consists of expressions and relations". What has the meaning of algebra is that Algebra is a subject that discusses expressions with symbols and numbers that are extended beyond integers to solve equations, analyze functional relationships, and determine the structure of a representation system consisting of expressions and relations. According to Kriegler, (2008) "algebra can be viewed as a tool for functions and mathematical modeling". What can be interpreted Algebra can be viewed as a tool for mathematical functions and modeling. Algebra is a part of mathematics that is very important to learn because it discusses and manipulates expressions and symbols to determine, solve a problem.

According to Lew algebra is not just a collection of facts and techniques, but algebra is a way of thinking. There are six ways of algebraic thinking according to Lew (2004), namely; Generalization, Abstraction, Analytical Thinking, Dynamic Thinking, Modeling, and Organization. In detail the process of algebraic thinking can be seen in table 1. 
Table 1. Indicators of Algebraic Thinking (Yusrina \& Masriyah, 2019)

\begin{tabular}{ll}
\hline Algebraic Thinking & \multicolumn{1}{c}{ Indicators of Algebraic Thinking } \\
\hline Generalization & $\begin{array}{l}\text { Identify relationships between objects and find the general pattern } \\
\text { or shape of a given set of objects. }\end{array}$ \\
\hline Abstraction & $\begin{array}{l}\text { Using symbols in the form of letters or pictures to represent } \\
\text { variables as unknown values based on generalizations. }\end{array}$ \\
\hline Dynamic Thinking & Solve problems using various methods. \\
\hline Modeling & Represent the situation in the problem into a mathematical mode. \\
\hline Analytical Thinking & $\begin{array}{l}\text { Solve problems by using equations to determine the value of a } \\
\text { variable as unknown. }\end{array}$ \\
\hline Organization & $\begin{array}{l}\text { Select and organize data by creating tables, or pictures, or diagrams, } \\
\text { or words, which can describe the problem situation and the } \\
\text { relationship between the overall problem conditions. }\end{array}$ \\
\hline
\end{tabular}

Table 1 is indicators of algebraic thinking. There are two factors that influence students' algebraic thinking skills, namely factors from within students and from outside students. One of the factors in students is independent learning. Learning independence affects students' mathematical abilities as in the research of Nurfadilah \& Hakim, (2019). Likewise on learning motivation, Tiara et al., (2019) revealed that learning motivation can affect achievement in learning mathematics. While the teacher as an educator becomes an external factor that affects students' mathematical abilities. The teacher's role in choosing how to deliver the material is very influential on the effectiveness in the learning process. It can be seen in the research results of Hakim et al., (2019), students who learn to use learning game applications have a higher ability increase than those who do not. Even though the concept of algebra in mathematics can be conveyed using the RME approach as presented by Chisara et al., (2018). The learning process can also be done with the help of peers and teachers. This learning process is called scaffolding Erlina \& Hakim, (2019). The process with the help of peers can be done in the environment during learning at school and outside school. One method that can be used is mobile learning. As revealed by Hakim, (2017) There are many advantages that can be obtained in implementing mobile learning.

Based on the explanation above, the difficulty of participants in understanding algebraic concepts and the importance of algebraic thinking skills in solving problems in both mathematics and other fields. One of the mathematical material that is closely related to algebra is a two-variable linear program. In solving problems in a two-variable linear program, an algebraic way of thinking is needed because in interpreting the problem students are required to model the mathematics of the problem in the problem. The twovariable linear program is the mathematics material given in class XI SMA. In the material 
for linear programming of two variables, there is material for linear inequalities of two variables and social arithmetic in determining the maximum/minimum value. This is the background for researchers to review algebraic thinking skills at the high school (SMA) level with the title "High School Students' Algebraic Thinking Skills in Solving 2 Variable Linear Program Problems". In this article, the researcher will describe how the algebraic thinking skills possessed by students in solving mathematical problems.

\section{METHOD}

The research approach used in this study is a qualitative approach. A qualitative approach will present quality data in the form of a description (Sugiyono, 2020). The method used in this research is descriptive analysis. In this study will describe the data descriptively. The analysis will be carried out based on indicators of algebraic thinking skills. This study aims to determine how high school students think algebraically in solving problems. This research was conducted by giving a test instrument to the research subject. The test instrument consists of three questions on two-variable linear program material taken from the "Mathematics Teacher's Book for SMA/MA/SMK CLASS XI 2013 revised 2017 curriculum" which has been validated by the government. The subject's answer will be analyzed in relation to algebraic thinking. The subjects consisted of three students of class XI who were selected by purposive sampling at one of the high schools in Karawang Regency. Subject selection is based on students' mathematical abilities.

\section{RESULTS AND DISCUSSION}

The results obtained After being given three linear programming problems in the test in the form of answers. There are several characteristics of problem solving with algebraic thinking skills. Problem analysis will refer to the algebraic way of thinking according to (Lew, 2004). According to Lew, (2004) the success of algebra is determined by 6 ways of thinking, namely, Generalization, Abstraction, Analytical Thinking, Dynamic Thinking, Modeling, and Organizing. In the first problem, students were asked to model the mathematics of the problem in question and to graph the set of solutions. The following is the form of the first question;

The first problem, students are given questions in the form of changing the information they have into mathematical form. The following questions are given: PT Lasin is a housing developer in a new residential area. The PT has a land area of 12,000 square meters and plans to build two types of houses, namely the rose type with an area of 
130 square meters and the jasmine type with an area of $90 \mathrm{~m}^{2}$. The number of houses to be built is no more than 150 units. The developer designs the profit for each house type of Rp. 2,000,000.00 and Rp. 1,500,000.00. Model the problem above! Then draw the solution area for the system of inequalities.

4. PT Lasin|adalah suatu pengembang perumahan di daerah pemukiman baru. PT tersebut memiliki tanah seluas 12.000 meter persegi berencana akan membangun dua tipe rumah, yaitu tipe mawar dengan luas 130 meter persegi dan tipe melati dengan luas $90 \mathrm{~m}^{2}$. Jumlah rumah yang akan dibangun tidak lebih 150 unit. Pengembang merancang laba tiap-tiap tipe rumah Rp2.000.000,00 dan Rp1.500.000,00.

\section{Figure 1. First Question}

The following are students' answers to the first question;

DATE misal mawar $=x$
tipe melati $=y$
$\Rightarrow 130 x+90 y \leqslant 12.000$
$13 x+9 y \leqslant 1200$
$\Rightarrow x+y \leqslant 150$
$\Rightarrow$ dan $x \geqslant 0, y \geqslant 0$
$\Rightarrow$ nilai maksimum $f(x, y)=2000 \cdot 000 x+1.500 \cdot 000 y$

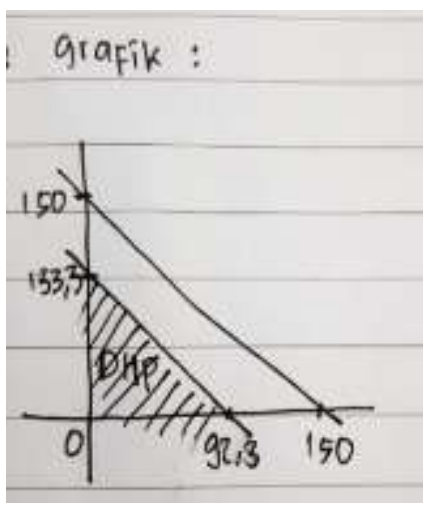

Figure 2. The Answer Of The First Student To The First Question

In Figure 2, the first student's answer to the first question shows that the student is able to answer according to the command of the first question. In students' answers, there is a modeling process according to the instructions in the questions. Students make mathematical models based on the correct information about the problem. There are two inequalities and an objective function. In the modeling process, the first student assumes the type of rose $=\mathrm{x}$ and the type of jasmine is $\mathrm{y}$. The separation process is one indicator of algebraic thinking skills, namely abstraction. However, in writing the example, the first student did not make an example correctly. The correct example for this problem is the number of rose-type houses and the number of jasmine-type houses. These errors can occur due to the generalization process or the identification of relationships between objects that the first student did not correctly. The second command, which is to determine the area of the set of solutions made correctly, is shown in Figure 2. However, the process of getting graphic images is not written by students. So it is doubtful that the first student meets the organizational indicators. In the first question, the first student identified the process of 
algebraic thinking, including Generalization, Abstraction, Modeling and Organization. But some of them are not done properly. Namely generalization, abstraction, and organization.

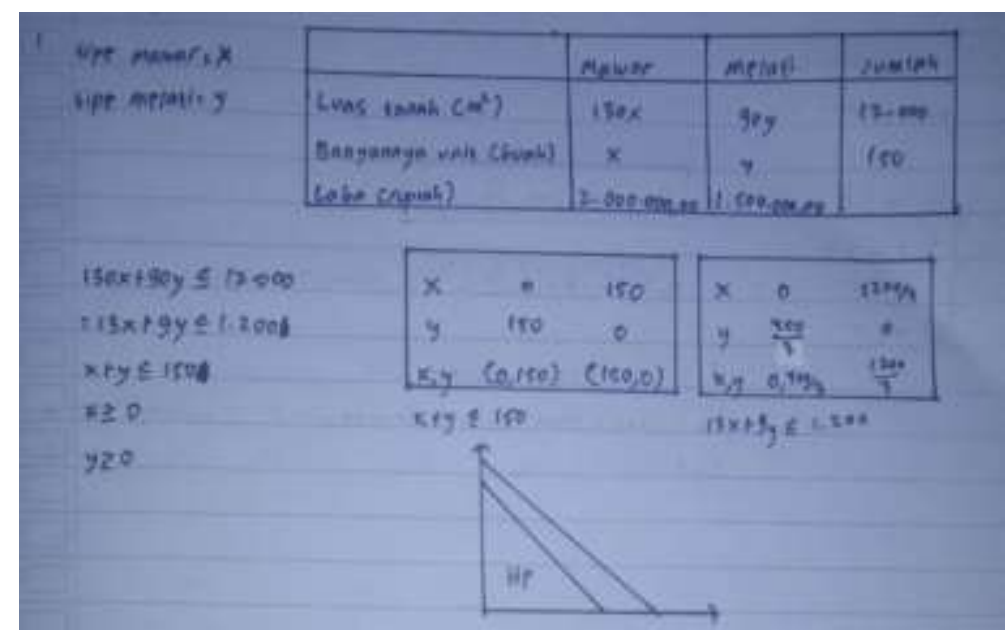

Figure 3. The Second Student's Answer To The First

It can be seen in Figure 3, in contrast to the first student, the second student does modeling with the help of tables. This is an organizational process in doing modeling. Similarly, in the process of finding the point of intersection on the $\mathrm{x}$ and $\mathrm{y}$ axes of each inequality. Although in some calculations the second student is not correct and does not write down the operation of simplifying inequalities. As was done in the inequality $130 x+90 y \leq 12000$ to $13 x+9 y \leq 1200$. The second student so far has also done several activities identified as algebraic thinking skills. The second student identified in the second problem using algebraic thinking which includes generalization, modeling, abstraction, and organization.
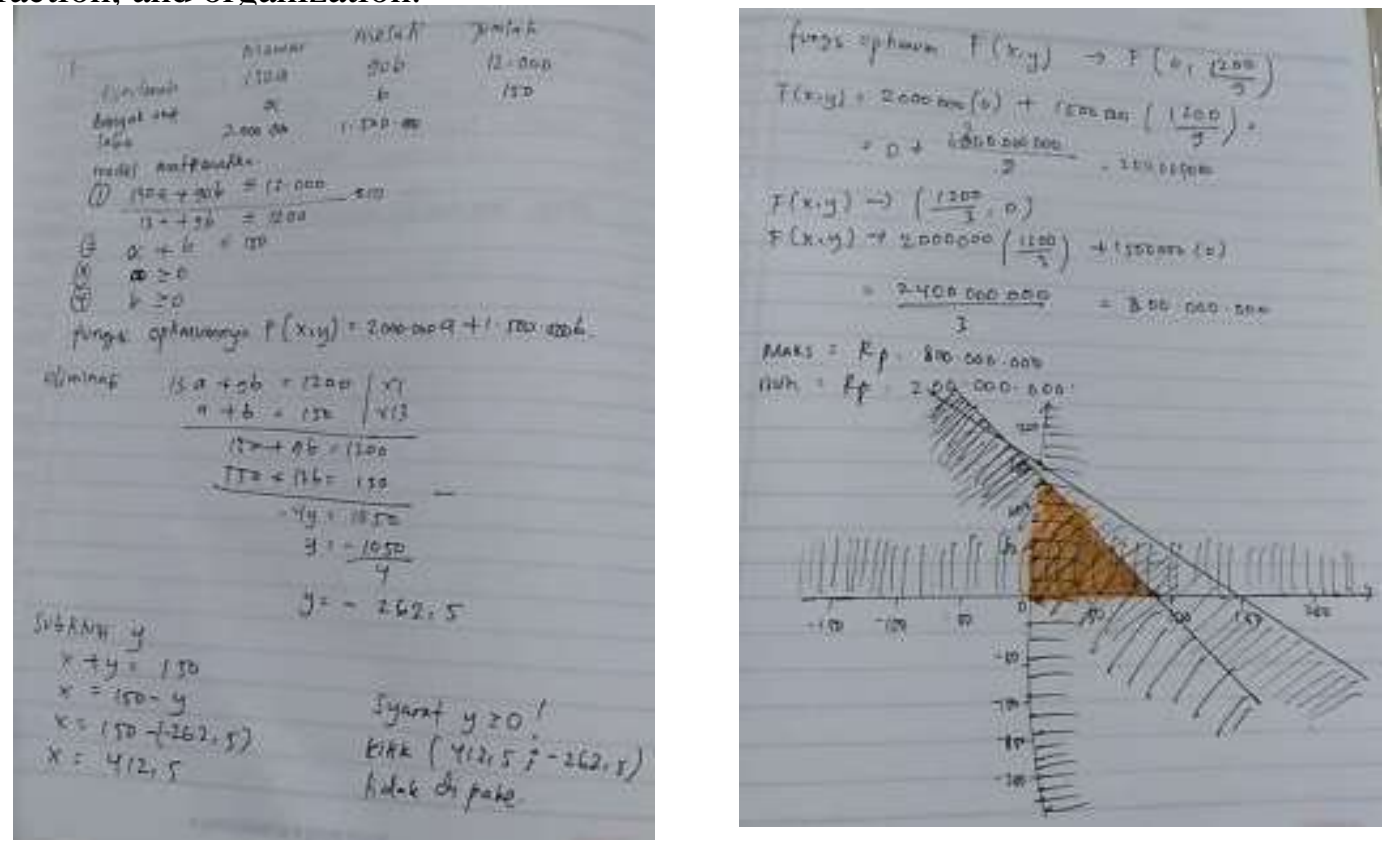

Figure 4. The Answers Of The Third Student To The First Question 
The third student in Figure 4, answered the first question quite completely. Starting from making mathematical models to finding the solution set area. Similar to the first student and second student, the third student did not correctly carry out the abstraction process where the example used by the third student was not quite right. Furthermore, in the process of determining the point of intersection of two inequalities, a variable change occurs, from the variable "b" to the variable "y". This is a conceptual error where the third student assumes that the variable must be $\mathrm{y}$ or $\mathrm{x}$. In the process of getting other answers, the third student tends to be better in analytical thinking. The third student is quite complete in answering the first question. This means that in the dynamic thinking process and analysis, the third student is superior to the first and second students. So it was concluded in the first question, the third student did algebraic thinking patterns including generalization, modeling, analytical thinking, and dynamic thinking.

The second question contains an order to determine the minimum value based on the information in the question. Here's the second question;

A transportation company must distribute 1200 packages (of the same size) via two haul trucks. Truck 1 loads 200 packages for each haul and truck 2 loads 80 packages for each haul. The transportation costs for truck 1 and truck 2 are Rp. 400,000.00 and Rp. 200,000 , respectively. Even though the available cost to transport 1200 packages is only IDR 3,000,000.00. Calculate the minimum cost of transporting the package.

Following are the students' answers to the second question;

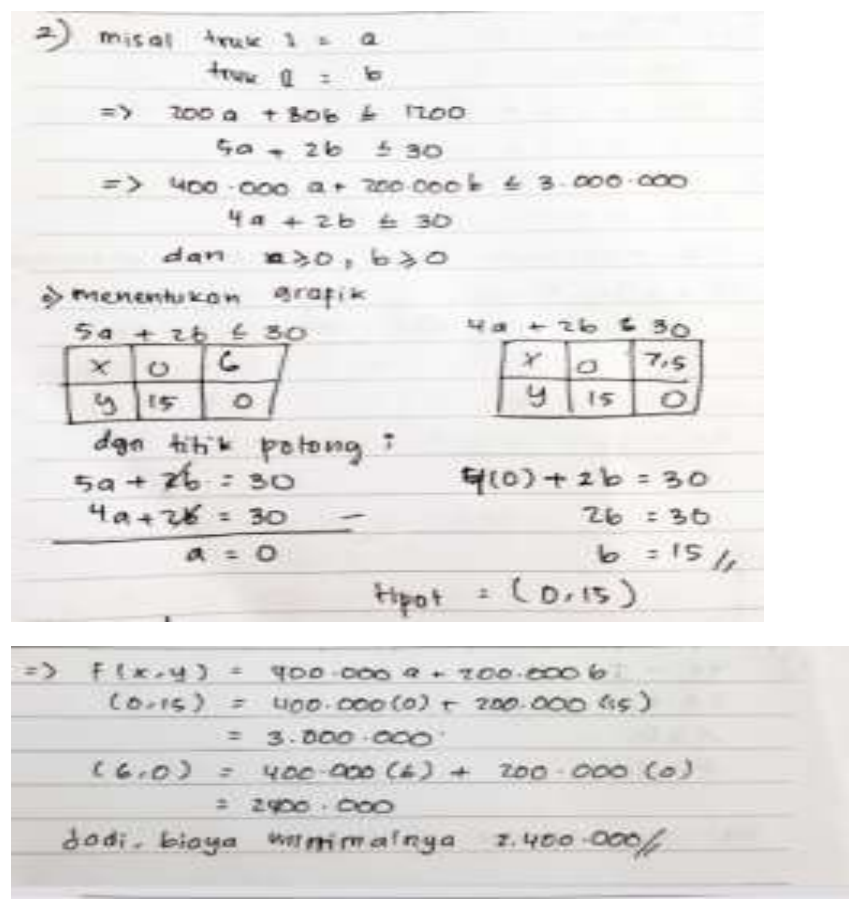

Figure 5. The Answer Of The First Student To The Second 
In the answer to the second question, it can be seen in Figure 5 that the generalization, abstraction and modeling processes are carried out in the same way. Likewise with errors that occur. In addition, it is also seen in Figure 5 organizational processes. The first student makes an auxiliary table based on the data they have to find 2 inequality lines. If you pay attention again, the first student is not consistent in using the example. In the table students use variables $\mathrm{x}$ and $\mathrm{y}$, while at the beginning of the work the first student uses $a$ and $b$ as variables. In Figure 5, the first student uses two stages of work in finding the intersection point. First, the first student uses the elimination method and continues with substitution. From the results of the procedure, students get the coordinates of the intersection point $(0,15)$.

Furthermore, in Figure 5, the first student substitutes the values of the corner points/extreme points that have been obtained into the objective function/objective function. So the first student concludes that the minimum cost value is $2,400,000$ which is obtained from the corner point substitution (6.0). In this work, the first student is able to think dynamically when determining the point of intersection on the $\mathrm{x}, \mathrm{y}$ axis, and between lines. The first student figured out a different way to find the point of intersection between lines. Where, to find the point of intersection between the lines, students use the method of elimination and substitution, while to find the point of intersection on the $\mathrm{x}$ and $\mathrm{y}$ axes, the first student uses the help of a table to get the point of intersection of each line with the $\mathrm{x}$ and $y$ axes. In addition, the analytical thinking indicator is seen in the way the first student solves the problem. The first student solves the exact problem using the equation. Starting from determining the point of intersection to getting the maximum value. However, the first student did not show arguments either in writing or graphically in choosing extreme points/corners. Based on the explanation, it can be concluded that to answer the questions the first two students use thinking skills. Among them are generalization, abstraction, modeling, analytical thinking, dynamic thinking, and organization. But of course, not done properly. There are some errors as described.

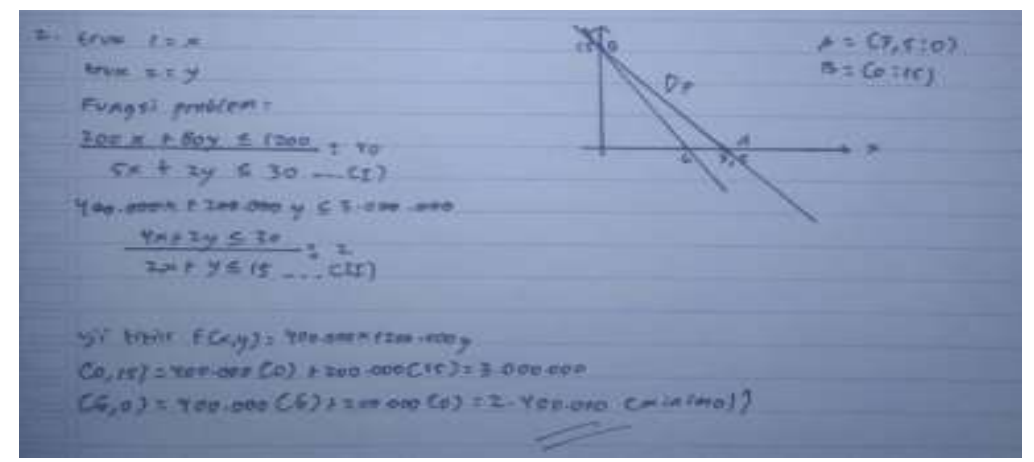

Figure 6. The Second Student's Answer To The Second Question 
In the second student's answer to the second question in Figure 6, there are many shortcomings. There is not even a complete mathematical modeling. Even though the obtained inequality is true and the simplification step of the first inequality becomes $5 x+2 y \leq 30$ and the second inequality $2 x+y \leq 15$ is also true. But the process to get it is not shown. So it can be concluded that the second student did not carry out the generalization or abstraction process. In addition, the second student repeated the error on the first test question. That is not writing in full the process of getting the area of the solution set and the intersection points in the graph. Even though in the final answer, students conclude correctly that the minimum score is $2,400,000$. Based on this, it can be concluded that the second student in question 2 did not perform analytical thinking patterns, dynamic thinking and organizing.
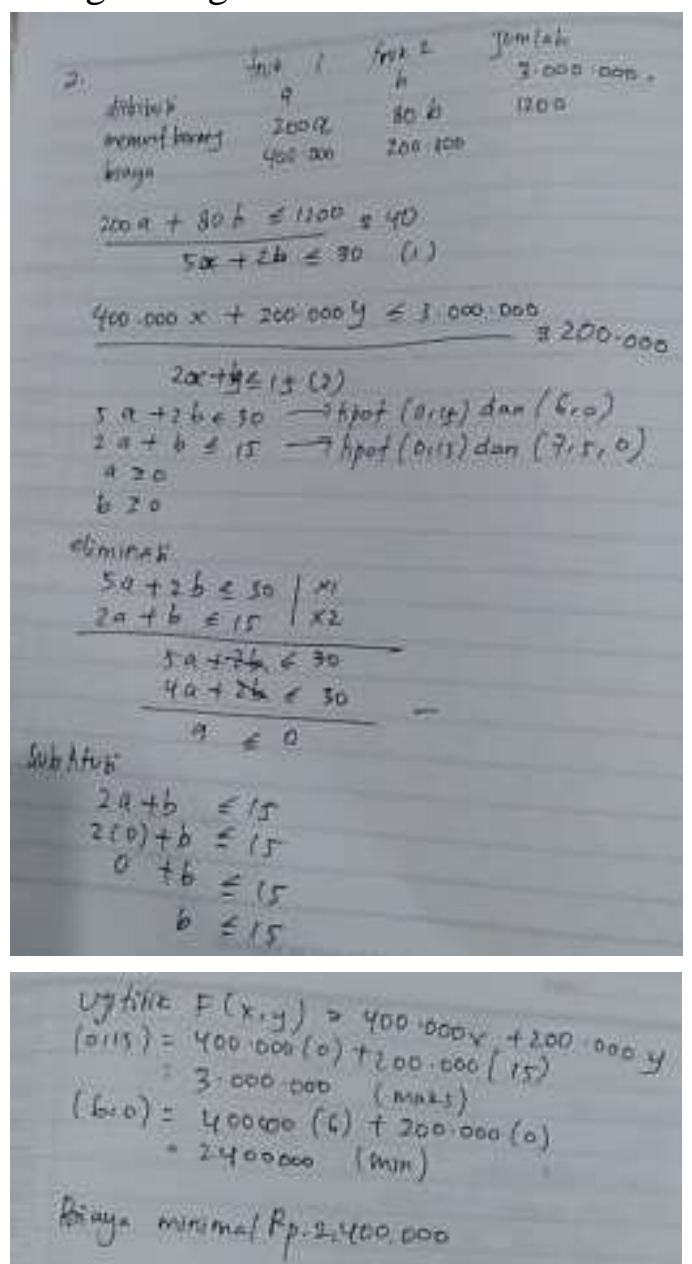

\section{Figure 7. The Third Student's Answer To The Second Question}

In the second question, the third student, repeated several mistakes. The first is the abstraction process, namely the example of an object that is less precise. Second, changes in the use of variables. In the first inequality and the objective function, student 3 uses "a" and " $b "$ as variables, while in the second inequality, the third student uses "x" and "y" as 
variables. In addition, the third student also did not use the settlement set area or graphic image as a reference for choosing corner points. So that it can lead to errors in concluding the final answer. Although on the second question the third student answered with the right ending. The third student in solving the second problem carried out the process of modeling, generalizing and thinking analysis.

The third question is a question with the command to find the maximum value of the existing problem. Here's the third question. Every six months, an ornamental plant business owner orders ornamental plants from a large agent; Aglaonema (A) and Sansevieria (S) which respectively gave a profit of Rp. 5,000,000.00 and Rp. 3,500,000.00 per unit sold. It takes quite a long time to produce an ornamental plant with super quality. Therefore, big agents have a rule that every order for ornamental plants A is at least $20 \%$ of all orders for other ornamental plants. The owner of the ornamental plant business has only enough land for 10 ornamental plants A or 15 ornamental plants S. In such a situation, how many ornamental plants A and S should be ordered (per semester) if it is known that at the end of the semester the old ornamental plants will definitely be sold out and the owner of the business wants to maximize total profit?

Here are the students' answers to the third question;

$$
\text { 3) } \begin{array}{rl}
4 A-5 & \geqslant 0 \\
3 & A+25 \leqslant 30 \\
x & \geqslant 0 \\
y & \geqslant 0
\end{array}
$$

Figure 8. The Answer Of The First Student To The Third Question

In Figure 3.1, it can be seen that the first student was unable to solve the problem on the third question. The first student works only on the formation of inequalities. However, the process of finding inequalities is not clearly written. So it cannot be concluded if the first student made generalizations and abstractions in the process of answering the third question. In the third answer by the first student, it was concluded that there were a few algebraic thinking processes carried out, namely abstraction and generalization. Although the process cannot be seen in its entirety. 


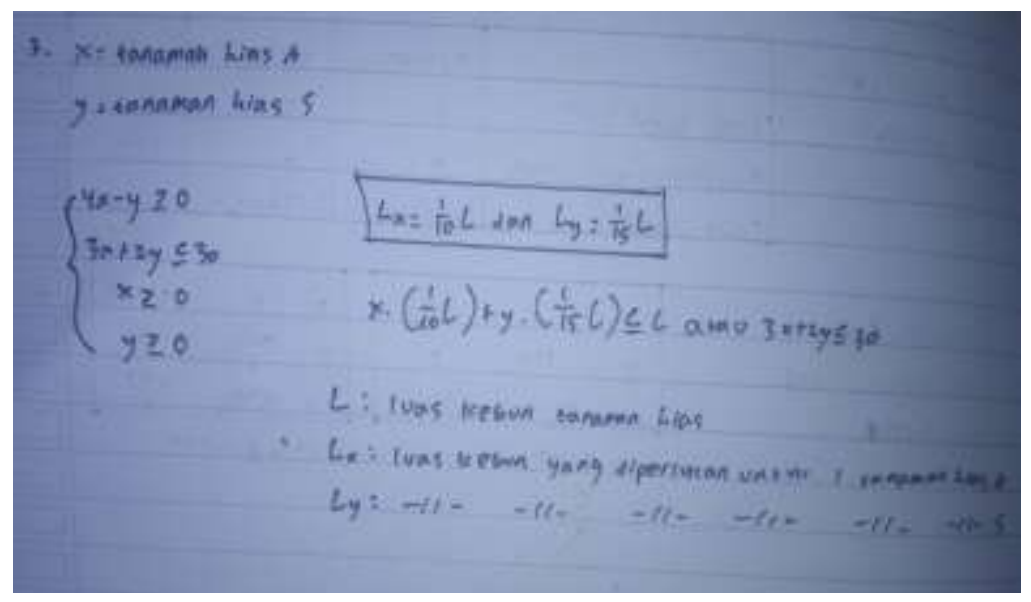

Figure 9. The second student's answer to the third question

Furthermore, the second student's answer to the third question in Figure 9. Similar to the first student, the second student also only completed the mathematical modeling stage. However, the second student shows the process of getting the second inequality. The second student also wrote down $\mathrm{x}$ as an ornamental plant $\mathrm{A}$ and $\mathrm{y}$ as an ornamental plant $\mathrm{S}$. The second student made an inequality obtained from the information on the maximum number of plants $\mathrm{A}$ and $\mathrm{S}$ on the land owned by the business owner. It is also seen that the second student wrote at the beginning of the soil inequality as $x\left(\frac{1}{10} L\right)+y\left(\frac{1}{15} L\right) \leq L$, then changed it to $3 x+2 y \leq 30$. However, the second student did not write down the operation or process of changing the form of the inequality. The generalization and abstraction process carried out by the second student on the third question was still better than the first student. From the second student's answer, it can be concluded that there is no analytical, dynamic and organizational thought process carried out.

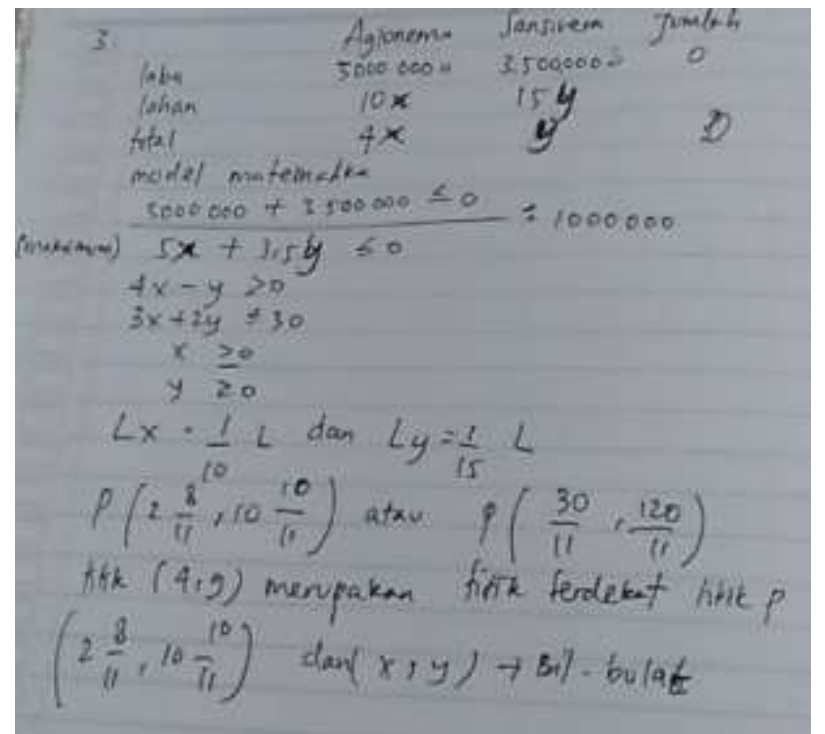

Figure 10. The Third Student's Answer To The Third Question 
In Figure 10, it can be seen that the third student's answer to the third question made an example using the help of a table. In addition, the third student was able to get the objective function even though it was still marked by inequality. Likewise with the second student, the third student is not very clear in writing down the origin or thought process that is carried out so that he gets the inequality of the problem. Even if the inequality is true. In addition, the third student also determines the point of completion of the problem. Even if the results are wrong. But in this case the third student tried several ways to solve the problem. So it can be concluded that the third student has 4 of the six algebraic thinking processes on the third question. Namely the generalization of abstraction and organizational modeling. However, it still has many shortcomings.

A brief description of high school students' algebraic thinking skills in solving problems on two-variable linear programming materials is as follows. Overall, students are able to make generalizations. This is shown in the discovery of equation patterns at the mathematical modeling stage. This is different from what was found by Turrosifah \& Hakim, (2019), where students are still not able to model mathematics. However, in this study, it can be seen that every student makes the same mistake. Each student has not made a mistake in assuming an object into the form of a symbol. In addition, students' understanding of the use of symbols or variables has not been maximized, this is indicated by changes in the variables or symbols used in the inequality.

Organizing is the process of understanding and presenting problems in the form of tables or graphs. Based on the previous explanation, each student is able to display the data into a graph. However, the first and second students have answers that do not show the completion process. The completion process that is not displayed is the result of students' unanalyzed ways of thinking. Students have not been able to understand algebraic concepts and problem solving procedures on the questions provided, such as in research (Suciati \& Hakim, 2018).

Meanwhile, the analytical and dynamic thinking processes were not clearly seen in the first, second, and third students. This is because students' answers do not show the complete calculation process in solving problems. Getting a conclusion on the answer does not mean that students have fulfilled their mathematical abilities, these results need to be reviewed for truth (Nurjanah \& Hakim, 2019)

The effectiveness of the learning process is very influential on the development of students' mathematical abilities. The use of appropriate learning models and media can increase the effectiveness of the learning process and the development of students' mathematical 
abilities. As pointed out by Hakim, (2017b), it is shown that the Sladermath game media can improve algebraic abilities better than ordinary learning. In fact, many teachers do not understand the importance of preparing teaching materials for Hakim's learning process, (2017a). Students need learning methods that maximize problem solving abilities. As revealed by Nurilah et al., (2018) about problem-solving-based learning models that can increase the effectiveness of the learning process. The results and discussion section presents the results obtained and how they were achieved and a discussion of research results must be linked to a literature review and includes the advantages, disadvantages, and limitations of the research. The description should be comprehensive but still concise and coherent.

\section{THANK-YOU NOTE}

. I express my gratitude to Allah SWT. who has given me good health so that I can finish this article as well as possible. In addition, I also do not forget to say thank you to those who helped in the preparation of this article, either directly or indirectly. Lastly, I would like to thank the publishers who have given me the opportunity to publish my articles in this journal.

\section{REFERENCES}

Arfianto, H., \& Hakim, D. L. (2019). Penalaran Matematis Siswa Pada Materi Fungsi. Prosiding Seminar Nasional Matematika Dan Pendidikan Matematik Sesiomadika 2019, 2018, 1248-1256.

Chisara, C., Hakim, D. L., \& Kartika, H. (2018). Implementasi Pendekatan Realistic Mathematics Education (RME) dalam Pembelajaran Matematika. Prosiding Seminar Nasional Matematika Dan Pendidikan Matematika (Sesiomadika), 65-72. http://journal.unsika.ac.id/index.php/sesiomadika

Erlina, \& Hakim, D. L. (2019). Kecerdasan Logis Matematis Siswa SMP pada Scaffolding. Sesiomadika, $1165-1173$. https://journal.unsika.ac.id/index.php/sesiomadika/article/view/2941

Hakim, D. L. (2017a). PELATIHAN PEMBUATAN BAHAN AJAR MATEMATIKA MEDIA PREZI. UNES Journal of Community Service, 2(2), 157-163.

Hakim, D. L. (2017b). Penerapan mobile learning dalam mengembangkan kemampuan komunikasi matematis, representasi matematis, dan kemandirian belajar matematika siswa [Universitas Pendidikan Indonesia]. http://repository.upi.edu/32320/ 
Hakim, D. L. (2017c). Penerapan Permainan Saldermath Algebra Dalam Pelajaran Matematika Siswa Kelas Vii Smp Di Karawang. JIPMat, 2(1). https://doi.org/10.26877/jipmat.v2i1.1476

Hakim, D. L., Mulyati, R., \& Sari, M. (2019). APLIKASI GAME MATEMATIKA DALAM MENINGKATKAN KEMAMPUAN MENGHITUNG MATEMATIS. 12(1), 129-141.

Hardianti, A., \& Kurniasari, I. (2019). KEMAMPUAN BERPIKIR ALJABAR SISWA SMP DALAM MENYELESAIKAN MASALAH MATEMATIKA. Jurnal Ilmiah Pendidikan Matematika, 1(5), 59-66.

Kriegler, S. (2008). Just WHAT IS ALGEBRAIC THINKING? Introduction to Algebra:TeacherHandbook, $1-11$. http://www.shastacoe.org/uploaded/SCMP2/Fall_Content_Day_2013/Fall_Content_D ay_2013_69/SCMP2_Winter_Content_Day_2014/SCMP2_Summer_Institute_2014/MAlgebraic_Thinking_Article_by_Kreigler.pdf

Kurniasih, R., \& Hakim, D. L. (2019). Berpikir Kritis Siswa Dalam Materi Segiempat. 2017, 1135-1145.

Lew, H.-C. (2004). Developing Algebraic Thinking in the Earlier Grades : A Case Study of the Chinese Elementary School Curriculum 1. The Mathematics Educator, 8(1), 107130.

Manullang, S. (Kemdikbud), Kristianto S, A. (kemendikbud), Hutapea, T. A., Sinaga, L. P., Sinaga, B., Marianus S, M., \& Snambela, P. N. J. M. (2017). MATEMATIKA: SMA/MA/SMK/MAK KELAS XI. In S. Mulyaningsih (Ed.), 4 Januari 2016 (1st ed.). Kementerian Pendidikan dan Kebudayaan. https://www.kemdikbud.go.id/main/blog/2016/01/7-provinsi-raih-nilai-terbaik-ujikompetensi-guru-2015

Mulbar, U. (2015). Pengembangan Desain Pembelajaran Matematika Dengan Memanfaatkan Sistem Sosial Masyarakat. Cakrawala Pendidikan, 2(12), 278-287. https://doi.org/https://doi.org/10.21831/cp.v2i2.4832

Nurfadilah, S., \& Hakim, D. L. (2019). Kemandirian Belajar Siswa dalam Pembelajaran $\begin{array}{llll}\text { Matematika. } & \text { Prosiding } & \text { Sesiomadika } & 2019,\end{array}$ http://journal.unsika.ac.id/index.php/sesiomadika

Nurilah, Hakim, D. L., \& Kartika, H. (2018). IMPLEMENTASI MODEL PROBLEM BASED LEARNING DALAM PEMBELAJARAN MATEMATIKA. 73-82.

Nurjanah, U., \& Hakim, D. L. (2019). Number Sense Siswa pada Materi Bilangan. 
Prosiding Seminar Nasional Matematika Dan Pendidikan Matematika Sesiomadika 2019, 1174-1182. http://journal.unsika.ac.id/index.php/sesiomadika

Retnowati, E. (2017). Efektivitas Strategi Pengelompokan Berpasangan Dalam Pembelajaran Matematika Model Core. Jurnal Cakrawala Pendidikan, 36(1), 13-23. https://doi.org/10.21831/cp.v35i1.12628

Suciati, D. R., \& Hakim, D. L. (2018). Koneksi Matematis pada Materi Kubus dan Balok. Jurnal Numeracy, 5(1), 57-66.

Sugiyono. (2020). Metode Penelitian Kuantitatif, Kualitatif, dan R\&D (Sutopo (ed.)). ALFABETA.

Tiara, P., Ayu, P., \& Hakim, D. L. (2019). MOTIVASI BELAJAR SISWA DALAM PROSES PEMBELAJARAN. 1146-1154.

Turrosifah, H., \& Hakim, D. L. (2019). Komunikasi matematis siswa dalam materi matematika sekolahan. Journal Homepage, 2000, 1183-1192. http://journal.unsika.ac.id/index.php/sesiomadika

Utami, R. E., Ekawati, C., \& Handayanto, A. (2020). Profil Kemampuan Berpikir Aljabar Dalam Memecahkan Masalah Matematika Ditinjau dari Gaya Kognitif Reflektif Siswa. 5, 13-24.

Yusrina, S., \& Masriyah, M. (2019). Profil Berpikir Aljabar Siswa Smp Dalam Memecahkan Masalah Matematika Kontekstual Ditinjau Dari Kemampuan Matematika. MATHEdunesa, 8(3), 477-484. 